\title{
Extensive Cross-reactivity Between Salsola kali and Salsola imbricata
}

\author{
Al-Ahmad M¹, Rodriguez-Bouza $\mathrm{T}^{2}$, Fakim N², Pineda $\mathrm{F}^{3}$ \\ 'Microbiology Department, Faculty of Medicine, Kuwait University, Kuwait \\ ${ }^{2}$ Al-Rashed Allergy Center, Ministry of Health, Kuwait \\ ${ }^{3}$ Diater Laboratories, Madrid, Spain
}

J Investig Allergol Clin Immunol 2018; Vol. 28(1): 29-36

doi: 10.18176/jiaci.0204

\begin{abstract}
Background: There are no studies on cross-reactivity between Salsola kali and Salsola imbricata pollens. The main goals of the present study were to compare the degree of the cross-reactivity between $S$ kali and S imbricata and to compare the various allergenic components shared by $S$ kali and S imbricata.

Methods: Serum samples were obtained from rhinitis patients with or without asthma living in Kuwait and presenting with a positive skin test result to $S$ kali. SDS-PAGE/lgE Western blot and ELISA inhibition assay were performed.

Results: The study population comprised 37 patients. The most frequent IgE proteins against $S$ imbricata weighed around 12, 15, 18, 37, and 50+55 kDa. 2D electrophoresis revealed a correlation between $S$ kali and $S$ imbricata at 40,60, and $75 \mathrm{kDa}$, with similar isoelectric points. ELISA inhibition revealed an Ag50 value of $1.7 \mu \mathrm{g} / \mathrm{mL}$ for $S$ kali and $500.5 \mu \mathrm{g} / \mathrm{mL}$ for $S$ imbricata when the solid phase was $S \mathrm{kali}$ and an Ag50 value of $1.4 \mu \mathrm{g} / \mathrm{mL}$ for $S$ kali and $3.0 \mu \mathrm{g} / \mathrm{mL}$ for $S$ imbricata when the solid phase was $S$ imbricata.

Conclusions: ELISA inhibition revealed strong cross-reactivity between $S$ kali and $S$ imbricata. This finding might be clinically relevant for the efficacy of allergen-specific immunotherapy. We report, for the first time, the allergenic profile of $S$ imbricata and potentially allergenic proteins for $S$ kali and S imbricata.
\end{abstract}

Key words: Allergens. Epitopes. IgE. Immunoblotting. Immunotherapy. Rhinitis. Salsola.

\section{Resumen}

Introducción: No existen estudios sobre la reactividad cruzada entre pólenes de Salsola kali y Salsola imbricata. El objetivo principal de este estudio es comparar el grado de reactividad cruzada entre Salsola kali y Salsola imbricata, y el objetivo secundario es comparar los diversos componentes alergénicos entre Salsola kali y Salsola imbricata.

Métodos: Se obtuvo suero de pacientes con rinitis con o sin asma, que vivieran en Kuwait y tuvieran un test positivo a Salsola kali. Se realizaron SDS PAGE/lgE Western blot, ELISA inhibición, a los sueros de pacientes kuwaitíes.

Resultados: Se incluyeron 37 pacientes kuwaitíes. Las proteínas que reaccionaron con más frecuencia contra Salsola imbricata se encontraron alrededor de 12, 15, 18, 37 y 50+55 kDa. La electroforesis 2D mostró una correlación entre Salsola kali y Salsola imbricata a 40, 60,

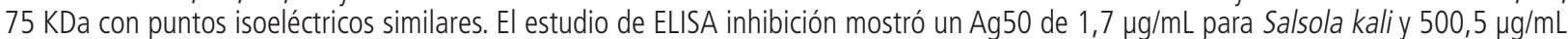
para Salsola imbricata cuando la fase sólida era Salsola kali, y un Ag50 de 1,4 $\mathrm{gg} / \mathrm{mL}$ para Salsola kali y 3,0 $\mu \mathrm{g} / \mathrm{mL}$ para Salsola imbricata cuando la fase sólida era Salsola imbricata.

Conclusión: Salsola kali y Salsola imbricata presentan una fuerte reactividad cruzada como se observa en el ELISA inhibición y esto podría ser clínicamente relevante para la eficacia de la inmunoterapia específica contra alérgenos. Hemos descrito por primera vez el perfil alergénico para Salsola imbricata y los posibles alérgenos comunes entre Salsola kali y Salsola imbricata.

Palabras clave: Alérgenos. Epítopos. IgE. Inmunoblotting. Inmunoterapia. Rinitis. Salsola. 


\section{Introduction}

Most patients with respiratory allergies in the State of Kuwait are sensitized to Salsola pollens [1], which are a predominant source of sensitization in the Gulf region [2,3] and Iran [4], as Salsola is prone to grow in salty soils in areas with low rainfall $[5,6]$. Salsola is also found in other dry countries such as the USA, Australia, and Spain [7-9]. Kuwait, a country of about $18000 \mathrm{~km}^{2}$ in the northwestern Arabian Gulf, has an arid climate. Natural vegetation is sparse and includes many species from the Chenopodium/Amaranthaceae family. Salsola imbricata grows widely in most parts of Kuwait and flowers in the summer, especially in September and October, when most pollensensitized patients become symptomatic. Salsola kali, however, has not been reported in Kuwait [10], although pollens can travel over considerable distances [11]. In the case of Chenopodium and Amaranthus species, the most prevalent plants in Kuwait are Chenopodium murale and Amaranthus lividus [10].

Studies in Kuwait have shown that Chenopodium pollens are the dominant type and are at their highest level during September and October [1].

Immunotherapy is an effective treatment for allergic rhinitis and bronchial asthma $[12,13]$ and has proven efficacious with $S$ kali [14]. Our allergy center has been using commercially available $S$ kali instead of $S$ imbricata pollen extracts for both skin testing and specific immunotherapy. About $70 \%$ of pollen-sensitized patients seen at our clinic react to $S \mathrm{kali}$ extract. However, the rationale for using an extract from a different, although closely related pollen for skin testing and immunotherapy has been questioned.

The main aims of this study were to compare cross-reactivity between $S$ kali and $S$ imbricata pollen extracts and to compare allergen components between $S$ kali and $S$ imbricata pollens.

Characterization of allergens of Salsola species has mainly been carried out with $S$ kali $[7,15]$. Sal k 1 is the major allergen, with a large number of isoforms. Since $S$ imbricata allergens have not been characterized, no studies have shown the allergenic profiles of both $S$ kali and $S$ imbricata pollens.

\section{Material and Methods}

\section{Study Population}

The inclusion criteria were residence in Kuwait, treatment at the Al-Rashed Allergy Center, allergic rhinitis with or without asthma, and a positive skin test result to $S$ kali. The diagnosis of allergic rhinitis was based on a compatible clinical history and symptoms affecting the nasal mucosa and turbinates, and asthma was confirmed in all cases as $\mathrm{FEV}_{1}(\%$ predicted $<80 \%$ in at least 1 measurement, with improvement of $\geq 12 \%$ after inhalation of a bronchodilator (salbutamol). Sensitization to $S$ kali was confirmed using skin prick tests (Diater). Written consent was obtained from all patients, and the study was approved by the Ethics Research Committee, Ministry of Health, Kuwait.

\section{Skin Testing}

All patients were tested with a battery of aeroallegens that included Dermatophagoides pteronyssimus, cat and dog dander, Alternaria, Aspergillus, Cladosporium, Phoenix dactylifera, Olea europea, 5-grass mix, Bermuda, Plantago, Amaranthus, Artemisa, Chenopodium album, and S kali. Skin prick tests were performed by a specially trained nurse on the volar surface of the forearms using skin prick test reagents (Diater) and metal lancets. The tests included a positive control (histamine solution) and a negative control (normal saline). The results were read after 15 minutes, and a wheal reaction of $\geq 3 \mathrm{~mm}$ was considered positive.

\section{Specific $\lg E$}

Levels of specific IgE to $S$ kali were measured using the ImmunoCAP specific IgE assay (Thermo Fisher Scientific). Values $\geq 0.35 \mathrm{kU} / \mathrm{L}$ were considered positive.

\section{S imbricata and S kali Pollens}

Pollen from locally grown $S$ imbricata was obtained by careful vacuuming and drying of plants. Pollen from $S$ kali, $C$ album, and Amaranthus retroflexus and peanut extract were purchased from Allergon. Proteins from all pollens and peanut were obtained in phosphate-buffered saline (PBS) $(1.37 \mathrm{mM}$ $\left.\mathrm{NaCl}, 14.7 \mathrm{mM} \mathrm{KH}_{2} \mathrm{PO}_{4}, 78.1 \mathrm{mM} \mathrm{Na}_{2} \mathrm{HPO}_{4}, 26.8 \mathrm{mM} \mathrm{KCl}\right)$ at $\mathrm{pH}$ 7.4. The homogenate was shaken magnetically for 30 minutes at $5 \pm 3^{\circ} \mathrm{C}$. The aqueous extract was obtained by filtering the soluble fraction through an AP 20 glass fiber filter (Merck Millipore) comprising a glass fiber prefilter and an 0.8mm membrane (AP membrane 2009000, Merck Millipore). It was then dialyzed against deionized water with membranes with a molecular cut-off of 3500 Da (Visking, Iberlabo) for 16 hours at $5 \pm 3^{\circ} \mathrm{C}$ before being stabilized by freeze drying.

\section{SDS PAGE/lgE Western Blot}

Proteins from $S$ kali, $S$ imbricata, C album, A retroflexus, and peanut extracts were analyzed using SDS-PAGE according to Laemmli [16] in $15 \%$ polyacrylamide gels under reducing conditions. Proteins were visualized using Coomassie Brilliant Blue R-250 staining and electrophoretically transferred to a polyvinylidene difluoride membrane (BioRad). IgE antibody binding to allergens was analyzed by Western blot using the patients' sera and antihuman IgE peroxidase conjugate (Southern Biotech). Chemiluminescence detection reagents (Western Lightning Plus-ECL, Perkin Elmer) were added. IgE binding bands were identified using the BioRad Diversity database program.

2D electrophoresis was performed using BioRad reagents and equipment. For the first dimension, 7-cm IPG strips ( $\mathrm{pH} 3-10)$. These were hydrated at $50 \mathrm{~V}$ and $20^{\circ}$ for 12 hours with $150 \mu \mathrm{L}$ of rehydration solution (8M urea, $50 \mathrm{mM}$ DTT, $2 \%$ [wt/vol] CHAPS, and 0.2\% [wt/vol] Byo-Lite $\mathrm{pH} 3-10$ ) containing 100-300 $\mu \mathrm{g}$ of each protein sample. Isoelectric focusing was conducted at $20^{\circ} \mathrm{C}$ as follows: S1, rapid voltage at $250 \mathrm{~V}$ for 15 minutes; S2, rapid voltage at $4000 \mathrm{~V}$ for 2 hours; S3, rapid voltage from 4000 to $10000 \mathrm{~V}$; and S4, rapid voltage at $500 \mathrm{~V}$ for 20 minutes. The limit voltage was $50 \mu \mathrm{A} /$ gel strip. After focusing, the gel strips were equilibrated with equilibration solution $\mathrm{I}(0.375 \mathrm{M}$ Tris- $\mathrm{HCl}$ at $\mathrm{pH} 8.8,6 \mathrm{M}$ urea, $20 \%$ [vol/vol] glycerol and 2\% [wt/vol] DTT) and equilibration solution II (0.375 M Tris- $\mathrm{HCl}$ at $\mathrm{pH} 8.8,6 \mathrm{M}$ urea, 20\% [vol/ 
vol] glycerol, $2 \%$ [wt/vol] SDS and $2.5 \%$ [wt/vol] IAA) by gentle shaking for 10 minutes. The IPG strip was embedded onto an SDS-PAGE gel (12.5\% separating gel). Gels were run at a constant current of $120 \mathrm{~V}$ for 20 minutes. The current was raised to $200 \mathrm{~V}$ per gel until complete.

\section{ELISA Inhibition Assays}

According to the level of cross-reactivity between $S$ kali and $S$ imbricata pollen extract in patients' sera, inhibition experiments were performed using the pollen extracts from $S$ kali and $S$ imbricata. ELISA inhibition was carried out using a modified protocol of Ceska and Lunkwist [17]. Briefly, $12.5 \mu \mathrm{g} /$ well of $S$ kali pollen extract in carbonate buffer (15 $\mathrm{mM} \mathrm{Na}_{2} \mathrm{CO}_{3}$ and $35 \mathrm{mM} \mathrm{NaHCO}_{3}, \mathrm{pH}$ 9.6) was incubated at $4^{\circ} \mathrm{C}$ overnight in a 96 -well microtiter plate (Nunc MaxiSorp). Each well was blocked for 1 hour at room temperature with 100 $\mu \mathrm{L}$ of $1 \%$ BSA in PBS-Tween $0.05 \%$, followed by incubation for 2 hours with pool sera and the specific amounts of each pollen extract preincubated at room temperature. The wells were incubated as follows: 30 minutes at room temperature with a 1:1000 dilution of antihuman IgE monoclonal E-27 IgG (Operon) in 1\% BSA in PBS-Tween 0.05\%; 30 minutes at room temperature with 1:500 dilutions of biotinylated antimouse

Table. Results of Specific lgE Testing

\begin{tabular}{|c|c|c|c|c|c|c|c|c|}
\hline$\#$ & Age & Sex & Disease & $\begin{array}{l}\operatorname{sigE} \text { Sal k, } \\
\mathrm{kU}_{\mathrm{A}} / \mathrm{L}\end{array}$ & $\begin{array}{c}\operatorname{sIgE~Sal~k~} 1, \\
\mathrm{kU}_{\mathrm{A}} / \mathrm{L}\end{array}$ & $\begin{array}{l}\text { Country } \\
\text { of Origin }\end{array}$ & $\begin{array}{l}\text { Other } \\
\text { Pollen }^{\mathrm{a}}\end{array}$ & Other \\
\hline 1 & 22 & $\mathrm{~F}$ & Rhinitis and asthma & 5.62 & 11.9 & Kuwait & Ber & Cat \\
\hline 2 & 60 & M & Rhinitis and asthma & 12.9 & 70 & Egypt & & Cat \\
\hline 3 & 45 & $\mathrm{~F}$ & Rhinitis and asthma & 9.81 & 27 & Kuwait & Amr, Ber & \\
\hline 4 & 24 & $\mathrm{M}$ & Rhinitis & 1.44 & 9.48 & Kuwait & & \\
\hline 5 & 31 & $\mathrm{M}$ & Rhinitis and asthma & 15.9 & 39.5 & Kuwait & Art, Ber, Che, Pln & Cat, Alt, date \\
\hline 6 & 23 & $\mathrm{M}$ & Rhinitis and asthma & $>100$ & $>100$ & Kuwait & Art, Ber, Che & Date \\
\hline 7 & 29 & $\mathrm{~F}$ & Rhinitis and asthma & 3.4 & 0.08 & Kuwait & & \\
\hline 8 & 52 & $\mathrm{~F}$ & Rhinitis and asthma & 0.49 & 0.02 & Kuwait & Che & \\
\hline 9 & 33 & $\mathrm{~F}$ & Rhinitis and asthma & 18.3 & 18.9 & Kuwait & Amr, Che & \\
\hline 10 & 30 & $\mathrm{~F}$ & Rhinitis and asthma & 3.19 & 10.9 & Syria & Che & Nuts \\
\hline 11 & 50 & $\mathrm{~F}$ & Rhinitis and asthma & 14.5 & 44.4 & Bangladesh & Ber, Che & \\
\hline 12 & 44 & M & Rhinitis and asthma & 2.16 & 13.5 & Kuwait & & \\
\hline 13 & 33 & $\mathrm{M}$ & Rhinitis and asthma & 4.23 & 6.59 & Egypt & & \\
\hline 14 & 16 & $\mathrm{M}$ & Rhinitis and asthma & 3.03 & 40.9 & Kuwait & Ber & \\
\hline 15 & 21 & $\mathrm{M}$ & Rhinitis & 2.69 & 26.2 & Kuwait & & Cat \\
\hline 16 & 58 & $\mathrm{M}$ & Rhinitis and asthma & 0.27 & 1.17 & Egypt & Che & \\
\hline 17 & 50 & $\mathrm{~F}$ & Rhinitis and asthma & 41.4 & $>100$ & Bangladesh & & \\
\hline 18 & 48 & M & Rhinitis and asthma & 4.04 & 0.27 & Bangladesh & & \\
\hline 19 & 58 & $\mathrm{~F}$ & Rhinitis and asthma & 1.19 & 3.38 & Kuwait & Ber, Che & \\
\hline 20 & 30 & $\mathrm{M}$ & Rhinitis and asthma & 3.98 & 11.5 & Kuwait & Che & Alt \\
\hline 21 & 56 & M & Rhinitis and asthma & 11.1 & 45 & Pakistan & & Cat \\
\hline 22 & 34 & $\mathrm{~F}$ & Rhinitis and asthma & 8.5 & 29.8 & Kuwait & & \\
\hline 23 & 22 & $\mathrm{~F}$ & Rhinitis & 3.89 & 20.3 & Kuwait & & $\mathrm{Dp}$ \\
\hline 24 & 48 & $\mathrm{~F}$ & Rhinitis and asthma & 2.78 & 8.23 & Egypt & & \\
\hline 25 & 31 & $\mathrm{~F}$ & Rhinitis and asthma & 1.87 & 4.13 & Kuwait & Ber & Date \\
\hline 26 & 36 & M & Rhinitis & 5.58 & 7.02 & Kuwait & & \\
\hline 27 & 47 & $\mathrm{M}$ & Rhinitis and asthma & 10.08 & 33.9 & Kuwait & Ber, Che & \\
\hline 28 & 46 & $\mathrm{M}$ & Rhinitis & 25.04 & 79.5 & Egypt & & \\
\hline 29 & 49 & $\mathrm{M}$ & Rhinitis and asthma & 2.44 & 2.63 & Kuwait & & Cat \\
\hline 30 & 42 & $\mathrm{~F}$ & Rhinitis and asthma & 8.85 & 32.3 & Kuwait & Art, Che & Cat \\
\hline 31 & 60 & $\mathrm{M}$ & Rhinitis and asthma & 4.47 & 9.03 & Egypt & Amr, Ber & \\
\hline 32 & 26 & $\mathrm{~F}$ & Rhinitis & 13 & 44.1 & Kuwait & Che & \\
\hline 33 & 55 & M & Rhinitis and asthma & 4.38 & 33 & Kuwait & Ber, Che & \\
\hline 34 & 49 & $\mathrm{~F}$ & Rhinitis and asthma & 10.08 & 27.7 & Kuwait & Che & \\
\hline 35 & 20 & $\mathrm{M}$ & Rhinitis & 1.39 & 4.95 & Kuwait & & \\
\hline 36 & 33 & $\mathrm{M}$ & Rhinitis and asthma & 20.07 & 77.2 & Egypt & Che & Cat \\
\hline 37 & 19 & $\mathrm{M}$ & Rhinitis and asthma & 3.25 & 16.08 & Kuwait & Ber & Cat, Dp \\
\hline
\end{tabular}

Abbreviations: Alt, Alternaria; Amr, Amaranthus; Art, Artemisia; Ber, Bermuda; Che, Chenopodium; Dp, Dermatophagoides pteronyssinus; Pln, Plantago. aPollen species other than Salsola to which the patient had a positive skin test result. 
IgG (Sigma Aldrich Química) in 1\% BSA in PBS-Tween $0.05 \%$; and 30 minutes with streptavidin peroxidase (Sigma Aldrich Química) at 1:250 in 1\% BSA in PBS-Tween 0.05\% and then with $50 \mu$ of 2,2'-azino-bis(3-ethylbenzothiazoline6-sulphonic acid).

\section{Results}

The study population included 37 patients ( 21 males and 16 females) with a mean age of 37.4 years (range, 15-60). Six patients presented with allergic rhinitis alone, and 31 presented with allergic rhinitis and asthma. All patients had lived in Kuwait for longer than 5 years.

All 37 patients had a positive skin test result to $S$ kali, with a wheal diameter of $4 \mathrm{~mm}$ to $15 \mathrm{~mm}$ (mean wheal size, $7.88 \mathrm{~mm}$ ).

Specific IgE levels were measured in all patients for both $S$ kali and recombinant Sal k 1, and all patients tested positive (Table).

\section{Protein Profiles of Pollens}

Proteins from $S$ kali and $S$ imbricata, were separated using SDS-PAGE under reducing conditions (Figures 1 and 2).

\section{IgE-Binding Profiles of Pollen Extracts}

Reactivity of sera to $S$ kali and $S$ imbricata pollens is shown in Figures 1 and 2. Several IgE binding components were revealed, with weights ranging from 10 to $75 \mathrm{kDa}$. As it was not possible to determine any bands for $S$ imbricata in the case of patients $10,12,22$, and 26 , these were excluded from the final results.

The IgE components that were most frequently reactive to $S$ kali pollen extract were a $43-\mathrm{kD}$ a protein that was compatible with Sal $\mathrm{k} 1$ and several proteins of $22 \mathrm{kDa}$ and $70 \mathrm{kDa}$. The most frequent IgE components reactive to $S$ imbricata pollen extract were several proteins at around 12, 15, 18, 37, and $50+55 \mathrm{kDa}$.

Western blot performed with $C$ album, $A$ retroflexus, and peanut did not show any consistent pattern of coincidence with the reactive proteins for $S$ kali and $S$ imbricata extracts (Figure 2)

The proteins from $S$ imbricata and $S$ kali were separated on a series of 2D gels (Figure $3 \mathrm{~A}$ ) run in parallel with a $\mathrm{pH}$ gradient of 4.5 to 8.5 and subsequently transferred to a PVDF membrane for incubation with a pool of sera from allergic patients. Several proteins from $S$ imbricata (Figure 3B) with a molecular size of approximately 15 to $100 \mathrm{kDa}$ were recognized by $\mathrm{IgE}$, including the following: $100 \mathrm{kDa}(\mathrm{pI}$, 4.7-5.1), $75 \mathrm{kDa}$ (pI, 5.5-5-7), $60 \mathrm{kDa}(\mathrm{pI}, 4.7-5.3), 55 \mathrm{kDa}$ (pI, 5.6-7.0), $50 \mathrm{kDa}(\mathrm{pI}, 4.5), 40 \mathrm{kDa}(\mathrm{pI}, 5.7-7.0), 30 \mathrm{kDa}$ (pI, 5.1-5.9), $20 \mathrm{kDa}(\mathrm{pI}, 4.8-5.6)$, and $15 \mathrm{kDa}$ (pI, 4.5-8.5). $\mathrm{IgE}$ recognized proteins from $S$ kali at $100 \mathrm{kDa}$ (pI, 5.2-5.7), $75 \mathrm{kDa}$ (pI, 5.2-8.0), $60 \mathrm{kDa}$ (pI, 4.5-5.0), $50 \mathrm{kDa}$ (pI, 5.4-5-7), $40 \mathrm{kDa}$ (pI, 5.1-6.8), $30 \mathrm{kDa}$ (pI, 5.4-5.9), $23 \mathrm{kDa}$ (pI, 4.7), and $18 \mathrm{kDa}(\mathrm{pI}, 4.8)$.

\section{Allergenic Potency and Cross-reactivity}

To determine the cross-reactivity of sera to Salsola species, we determined Ag50 values for each pollen extract using ELISA inhibition (Figure 4). The Ag50 value was $1.7 \mu \mathrm{g} / \mathrm{mL}$ for $S$ kali extract and, theoretically, $500.5 \mu \mathrm{g} / \mathrm{mL}$ for $S$ imbricata when the pollen extract coated to the solid phase was $S$ kali; however, when the pollen extract coated to the solid phase was $S$ imbricata, the Ag50 value of $S$ kali pollen extract was $1.4 \mu \mathrm{g} / \mathrm{mL}$ and the Ag50 value of $S$ imbricata was $3.0 \mu \mathrm{g} / \mathrm{mL}$.

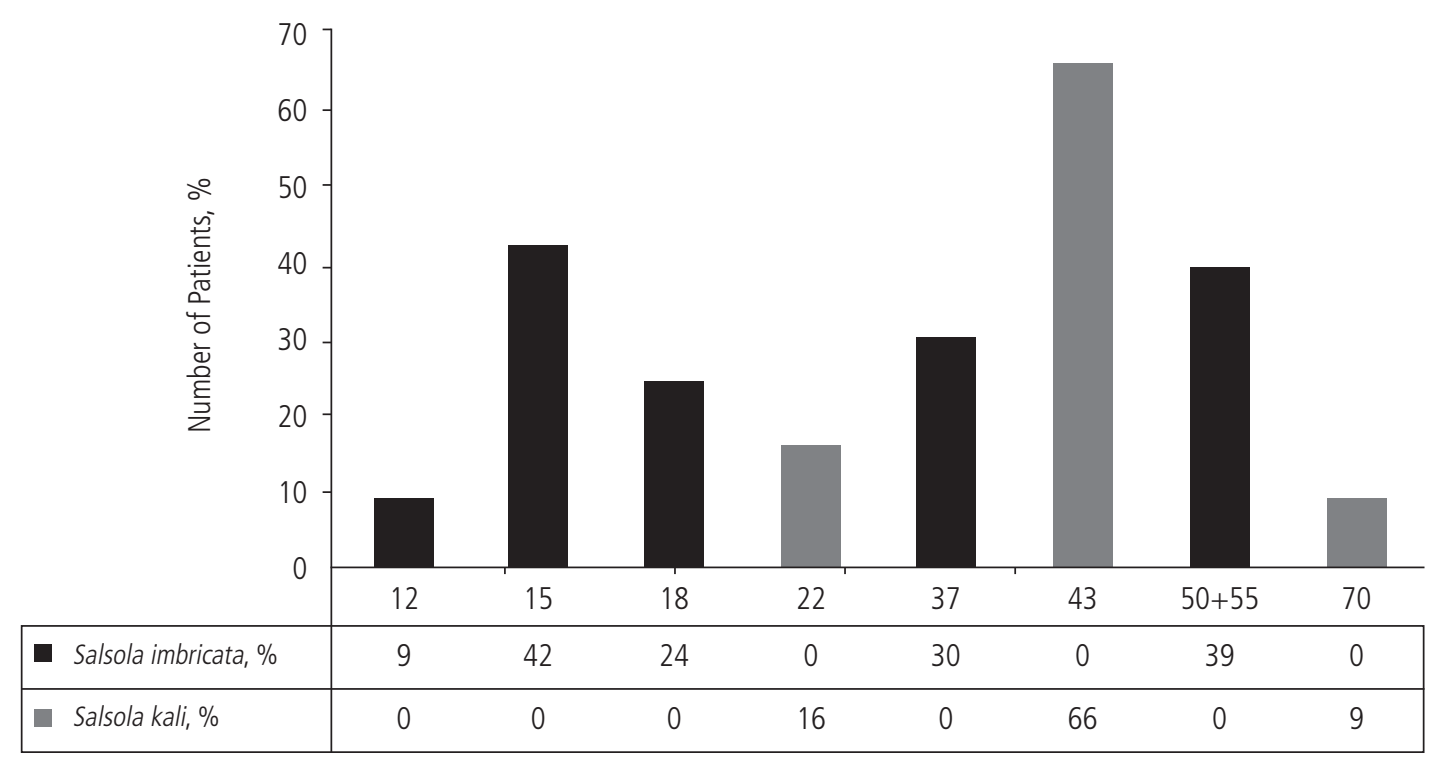

Figure 1. Frequency of IgE reaction with SDS-PAGE-separated allergens of Salsola kali and Salsola imbricata pollen extracts. 
Western Blot

Salsola kali pollen extract
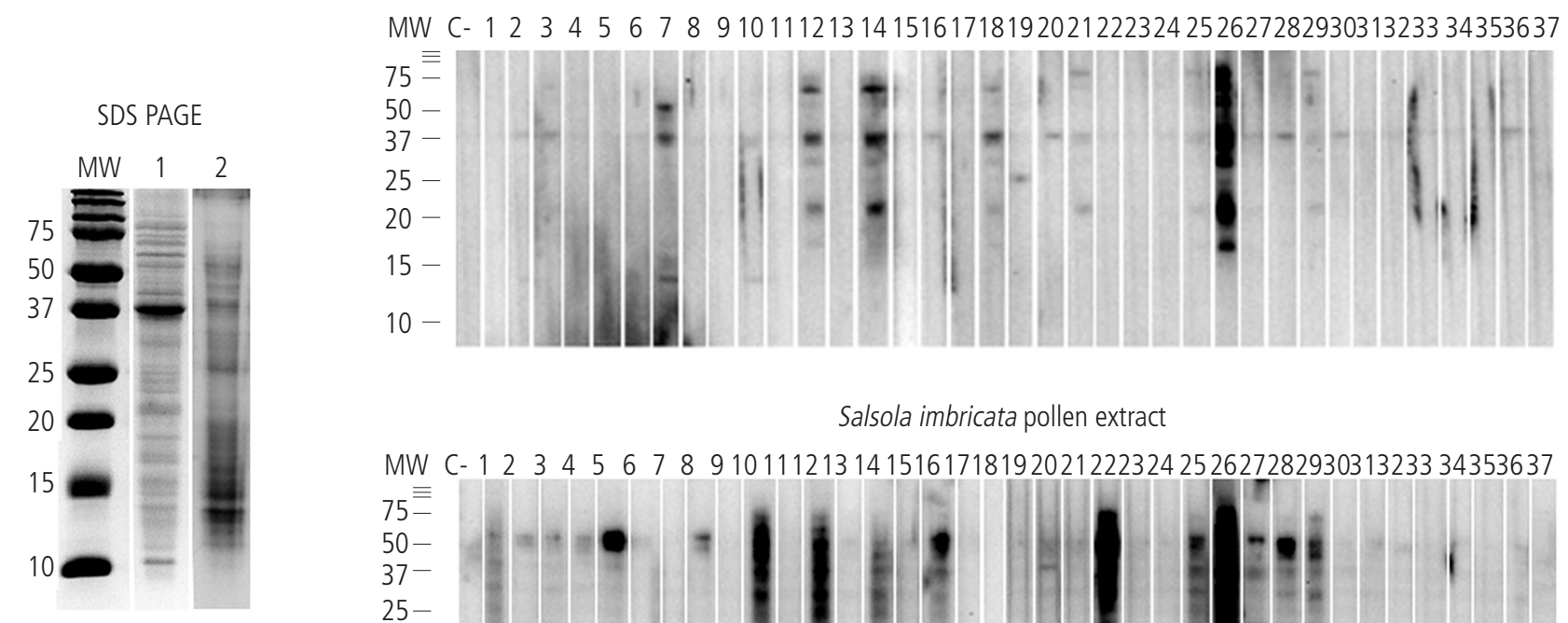

Salsola imbricata pollen extract

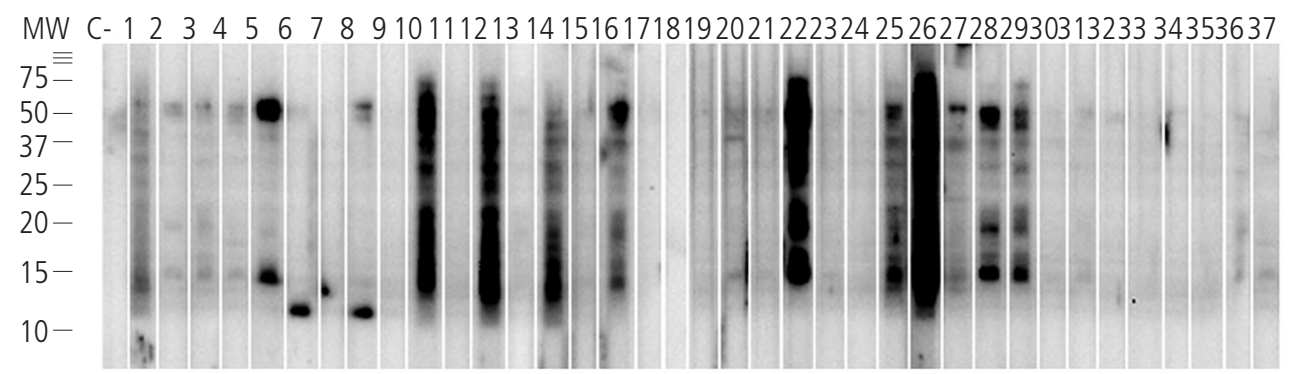

Chenopodium album extract

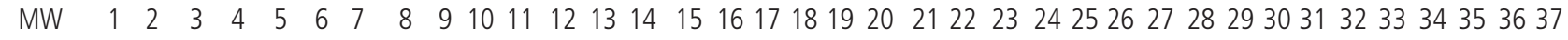

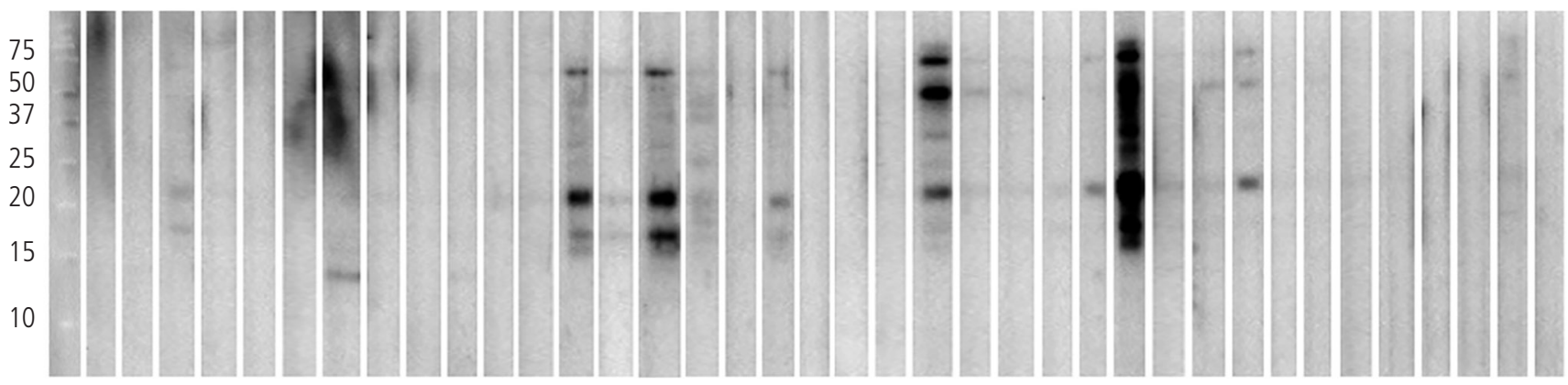

Amaranthus retroflexus extract

MW $\quad 1 \quad 2 \quad 3 \quad 4 \quad 5 \quad 6 \quad 7 \quad 8 \quad 91011 \quad 12131415161718192021222324252627282930313233 \quad 34353637$

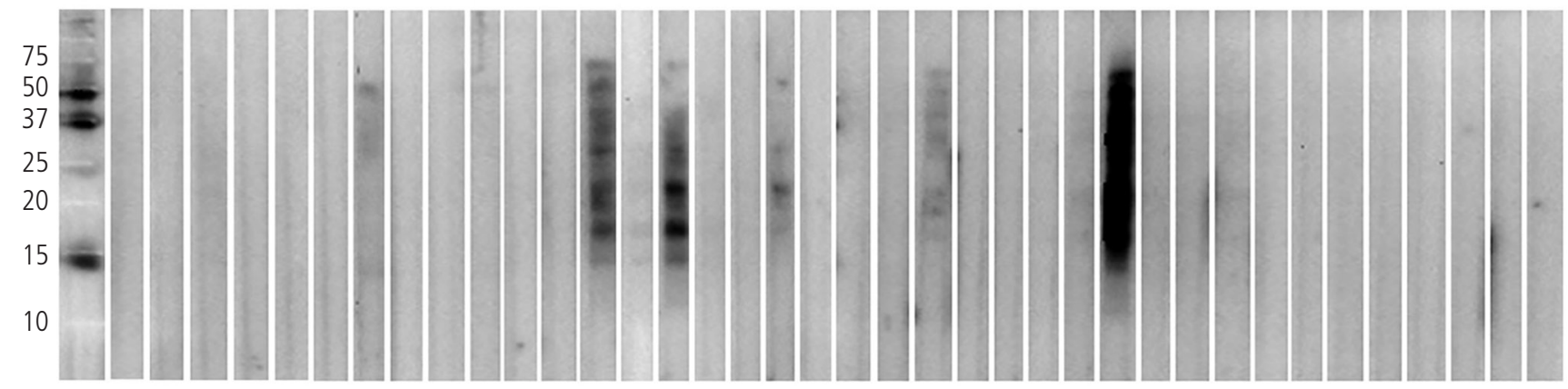

Figure 2. SDS-PAGE performed with Salsola kali (lane 1) and Salsola imbricata (lane 2). Western Blot performed with Salsola kali, Salsola imbricata, Chenopodium album, Amaranthus retroflexus, and patients' serum. 
A

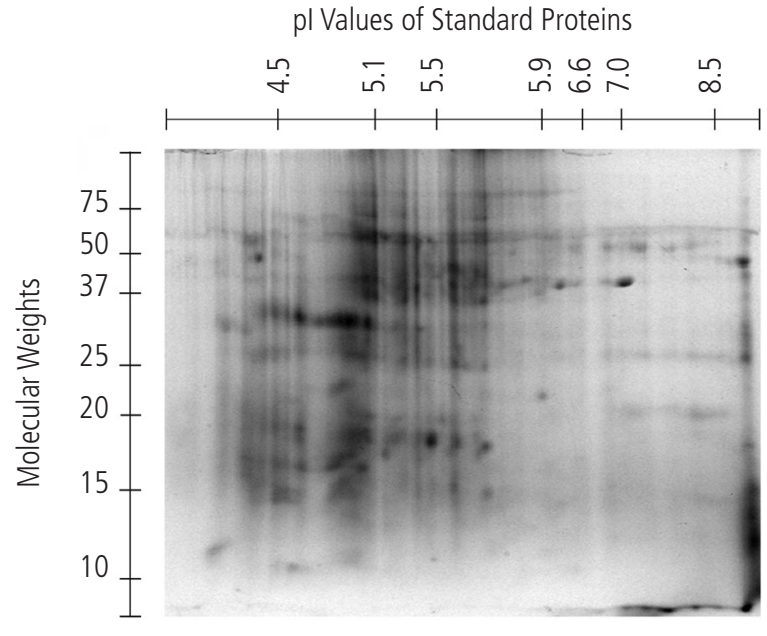

B

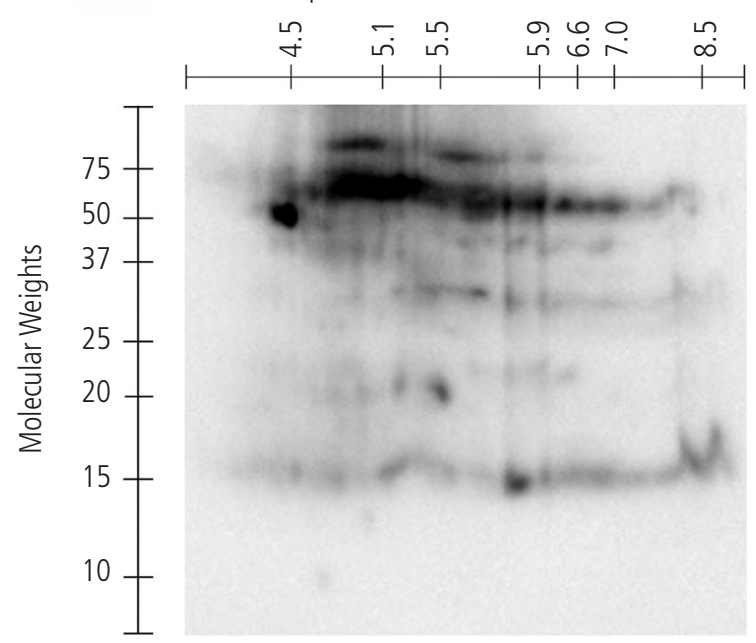

Salsola kali pl Values of Standard Proteins

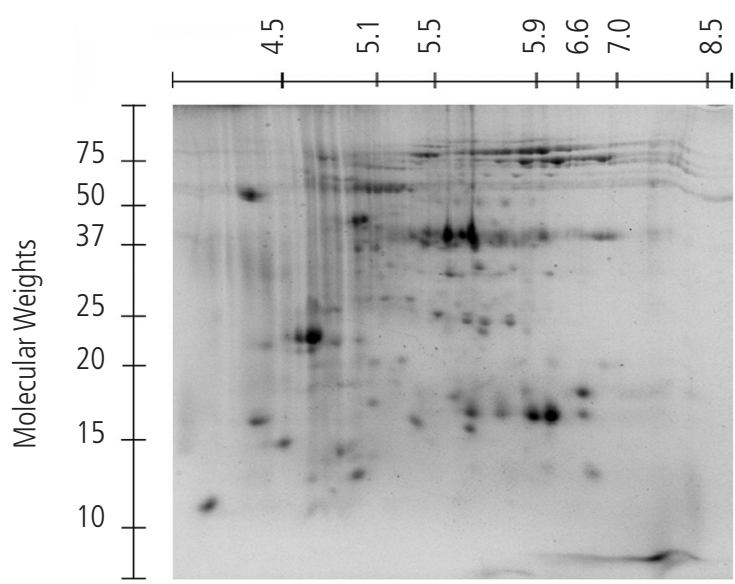

Salsola kali pl Values of Standard Proteins

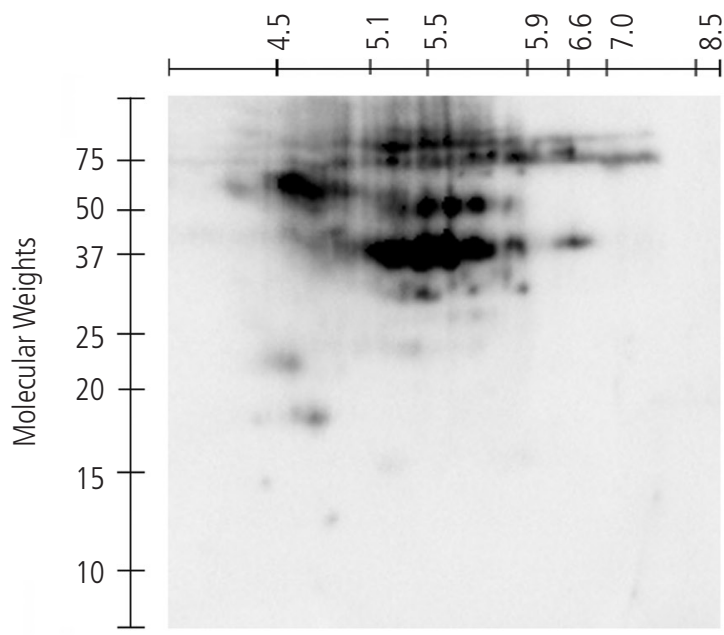

Figure 3. SDS-PAGE (A) and western blot (B) 2D of allergenic extract of Salsola kali vs Salsola imbricata, with a pool of sera from patients sensitized to Salsola imbricata.

\section{Discussion}

The allergenic profile of $S$ imbricata pollen has not been studied; therefore, major and minor $S$ imbricata allergens have not been described or isolated. However, cross-reactivity between Salsola and other species of Chenopodium is well established [7]. The binding observed for $S$ imbricata at $50+55 \mathrm{kDa}$ and $37 \mathrm{kDa}$ has not been previously reported, and the allergen is not predominant in any of the most common pollens of Kuwait such as Chenopodium (10-17kDa), Bermuda (9-32 kDa), and Amaranthus $(14,18 \mathrm{kDa})[1,18]$. In order to find a common source of sensitization that could explain possible cross-reactivity patterns for $S$ kali and $S$ imbricata, Western blot was performed with $C$ album and $A$ retroflexus; however, no clear correlations with any of the major binding components obtained were observed. Western blot was performed with peanut owing to previously described crossreactivity with $S$ kali proteins [19]. Binding with peanut has not been described in other predominant pollens from the Gulf region, such as Prosopis juliflora (18 kDa) [3] Furthermore, Phoenix dactylifera presents with allergens at 14, 40, and $90 \mathrm{kDa}$. Binding at 12,15 , and $18 \mathrm{kDa}$ could be related to profilins, although the nature of these bands should be characterized.

Increased prevalence of Sal k 1 in patients sensitized to foods and other pollens has been reported [20]. However, when the bindings obtained for $S$ kali and $S$ imbricata were correlated patient-by-patient, we found no clear relationship with cosensitization to other pollens or foods that could clarify the possible cross-reactivity with Sal k 1 or any of the main 
A

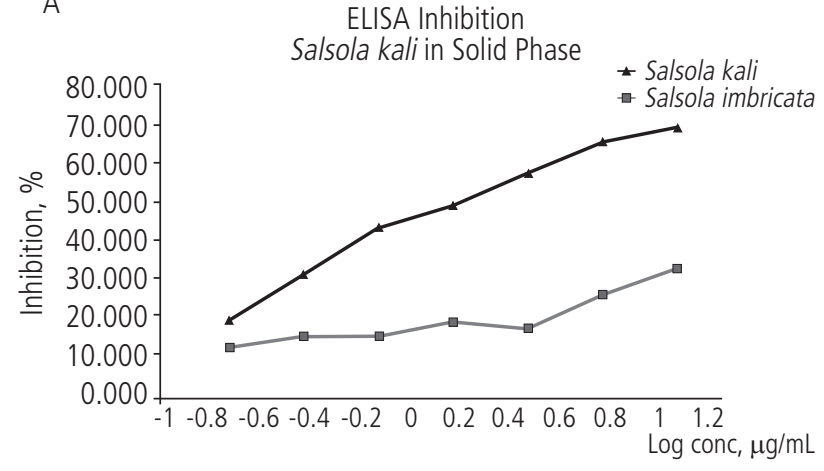

B

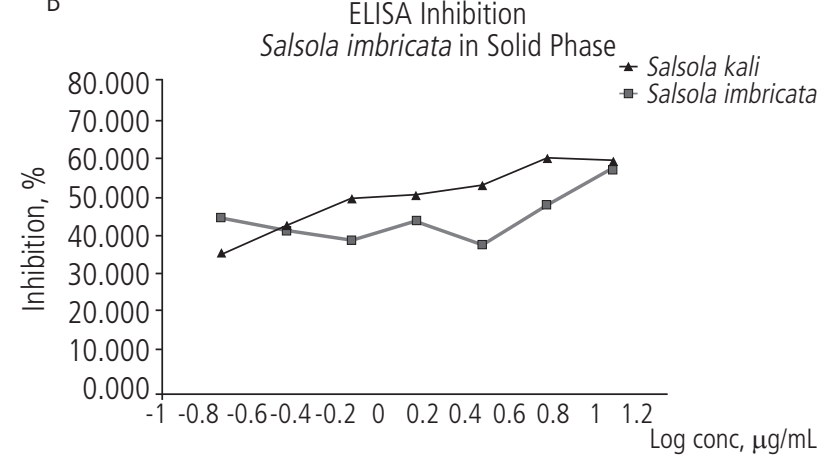

Figure 4. ELISA inhibition of allergenic extract of Salsola kali and Salsola imbricata with Salsola kali as solid phase. B, Salsola kali vs Salsola imbricata with Salsola imbricata as solid phase.

bands detected for S imbricata. Similarly, no clear correlation was observed between Sal k 1 and the main bands detected for $S$ imbricata. This finding was somewhat unexpected, as all patients had positive skin test results and specific IgE against $S$ kali and several bands were clearly recognized for $S$ kali. Moreover, we found no correlation with the country of origin. Although S kali is not present in Kuwait [10], we are aware of the possibility that $S$ kali pollen might travel long distances from nearby regions and hence be a source of sensitization for the study patients. Since patients living in Kuwait do not seem to clearly recognize the Sal k 1 counterpart in S imbricata, it is unlikely that inhibition of Sal k 1 would give clear results in the inhibition assay.

We detected 3 areas of common reactivity in 2D Western blot. The first was at $40 \mathrm{kDa}(\mathrm{pI}, 5.7-7.0)$ for $S$ imbricata and $40 \mathrm{kDa}$ (pI, 5.1-6.8) for S kali, both of which findings correlate with those previously described for Sal k 1 [7] [18], although the bands for S imbricata were weaker, suggesting that crossreactivity may be only partially explained by a common Sal k 1 protein. The second area was found at $75 \mathrm{kDa}$ (pI, 5.5-5-7) for $S$ imbricata and $75 \mathrm{kDa}(\mathrm{pI}, 5.2-8.0)$ for $S$ kali; this area might be related to Sal k 3. The third area was at $60 \mathrm{kDa}(\mathrm{pI}$, 4.7-5.3) for $S$ imbricata and $60 \mathrm{kDa}(\mathrm{pI}, 4.5-5.0)$ for $S$ kali, although these findings require further characterization.

The main goal of the present study was to compare crossreactivity between $S$ kali and $S$ imbricata owing to the clinical implications of a theoretically decreased response to $S$ kali immunotherapy in a country where $S$ kali is not present. Despite the incomplete concordance between S kali and S imbricata IgE binding profiles on Western blot, ELISA inhibition presented similar potency for inhibition when $S$ imbricata was in the solid phase and a clear preference for $S$ kali when $S$ kali was in the solid phase. Consequently, binding was stronger for the predominantly European $S$ kali than for the local $S$ imbricata. This may be because our patients are exposed to a number of other highly cross-reacting pollens (Chenopods and Amaranthaceae).

Aerobiology studies in Kuwait have shown a recurring pattern: the total atmospheric pollen count increases in summer, with a lesser peak in March/April and a significantly more pronounced peak in October/November. These periods also correspond to increased symptoms in the study patients. Pollens in March/April comprise mainly grass pollen but also Chenopod/Amaranthaceae pollens; in October/November they consist mainly of Chenopod/Amaranthaceae pollens. $C$ album and $\mathrm{C}$ murale, together with several Amaranthus species (Amaranthus hybridus, Amaranthus lividus), are fairly common. However, nearer to inhabited areas, $S$ imbricata is abundant on disturbed ground and along roadsides, where it flowers throughout summer, although more markedly in October/November, before it fruits.

The absence of greater similarity between the protein patterns in the SDS-PAGE analysis of the pollens of $S$ kali and $S$ imbricata, together with the strong inhibition by $S$ kali allergens in ELISA, suggests that other Chenopod/ Amaranthaceae pollens may be involved in the sensitization of the study patients, who are routinely skin tested (and often undergo specific IgE testing) with pollen extracts of $S$ kali, $C$ album, and $A$ retroflexus. $S$ kali is almost always the most reactive.

A recent study of adherence to $S$ kali immunotherapy in Kuwait [21] indirectly suggests that subcutaneous immunotherapy with $S$ kali is effective in the study population, who are exposed to $S$ imbricata pollen but not to $S$ kali pollen. The results of ELISA inhibition suggest that immunotherapy with $S$ kali extracts could be even more effective than immunotherapy with local $S$ imbricata extracts, although further studies are needed to confirm this observation.

The limitations of the study include differences in the methods used to collect $S$ kali and $S$ imbricata pollens, which might have affected the results, even though the protein concentrations for immunoblot and ELISA inhibition were equal. The collection process could have specifically affected the protein profiles of Salsola owing to the presence of immature or already germinated pollen at the time of collection. Methacholine challenge testing was not performed in patients presenting with allergic rhinitis and no clinical evidence of bronchial asthma in order to check for evidence of airway hyperresponsiveness. Further studies are needed to confirm these findings.

In conclusion, $S$ kali and $S$ imbricata present with a strong pattern of cross-reactivity, as shown in ELISA inhibition. We report the first allergenic profile for $S$ imbricata with protein bands at $12,15,18,27$, and $50+50 \mathrm{kDa}$ on immunoblotting in patients where sensitization to $S$ imbricata is predominant. We describe several possible common allergenic proteins 
for $S$ kali and $S$ imbricata at 40,60, and $75 \mathrm{kDa}$ with similar isoelectric points.

\section{Funding}

The authors declare that no funding was received for the present study.

\section{Conflicts of Interest}

Dr. Pineda reports being employed by Diater Laboratories, a pharmaceutical company specializing in the production of allergenic extracts for in vivo diagnosis and treatment of allergies. The remaining authors declare that they have no conflicts of interest.

\section{References}

1. Al-Dowaisan A, Fakim N, Khan MR, Arifhodzic N, Panicker R, Hanoon $A$, et al. Salsola pollen as a predominant cause of respiratory allergies in Kuwait. Ann Allergy Asthma Immunol. 2004:92:262-7.

2. Al-Tamemi SH, Al-Shidhani AN, Al-Abri RK, Jothi B, Al-Rawas OA, Al-Riyami BM. The pattern of sensitisation to inhalant allergens in omani patients with asthma, allergic rhinitis and rhinoconjunctivitis. Sultan Qaboos Univ Med J. 2008;8:31924.

3. Hasnain SM, Al-Frayh AR, Subiza JL, Fernandez-Caldas E, Casanovas M, Geith T, et al. Sensitization to indigenous pollen and molds and other outdoor and indoor allergens in allergic patients from saudi arabia, United arab emirates, and Sudan. World Allergy Organ J. 2012;5:59-65.

4. Fereidouni M, Hossini RF, Azad FJ, Assarehzadegan MA, Varasteh A. Skin prick test reactivity to common aeroallergens among allergic rhinitis patients in Iran. Allergol Immunopathol (Madr). 2009;37:73-9.

5. Crimi N, Palermo B, Palermo F, Pistorio MP, Rizza S, Mistretta $A$, et al. On the pollen morphology and frequency of allergic sensitization in Sicily of the genus Salsola L. (Chenopodiaceae). Allergol Immunopathol (Madr). 1988;16:259-62.

6. Omar SA A-MY, Zaman S. Vegetation of Kuwait: A Comprehensive Illustrative Guide to the Flora and Ecology of the Desert of Kuwait. Shuwaikh, Kuwait Institute for Scientific Research, 2000

7. Villalba M, Barderas R, Mas S, Colas C, Batanero E, Rodriguez R. Amaranthaceae pollens: review of an emerging allergy in the mediterranean area. J Investig Allergol Clin Immunol. 2014;24:371-81; quiz 372 p preceding 382.

8. Pola J, Subiza J, Zapata C, Moral A, Feo F, Aerobiology Committee of the Spanish Society of $A$, et al. Correlation between total annual atmospheric pollen counts for Chenopodiaceae--Amaranthaceae and the prevalence of positive skin prick tests to Chenopodium and/or Salsola pollen extracts: a multicenter study. J Investig Allergol Clin Immunol. 2009:19:73-4.

9. Colas C, Monzon S, Venturini M, Lezaun A, Laclaustra M, Lara $S$, et al. Correlation between Chenopodiacea/Amaranthacea pollen counts and allergic symptoms in Salsola kali monosensitized patients. J Investig Allergol Clin Immunol. 2005; 15:254-8
10. Kubec K, Selim MM, Al-Ghareer HA. Epidemiology of the mycotic flora in Kuwait. Mykosen. 1986;29:71-5.

11. Galan C, Antunes C, Brandao R, Torres C, Garcia-Mozo $H$, Caeiro $E$, et al. Airborne olive pollen counts are not representative of exposure to the major olive allergen Ole e 1. Allergy. 2013;68:809-12.

12. Dominguez-Ortega J, Delgado J, Blanco C, Prieto L, Arroabarren E, Cimarra $M$, et al. Specific allergen immunotherapy for the treatment of allergic asthma: a review of current evidence. J Investig Allergol Clin Immunol. 2017;27:1-35.

13. Karakoc-Aydiner E, Eifan AO, Baris S, Gunay E, Akturk E, Akkoc T, et al. Long-Term Effect of Sublingual and Subcutaneous Immunotherapy in Dust Mite-Allergic Children With Asthma/ Rhinitis: A 3-Year Prospective Randomized Controlled Trial. J Investig Allergol Clin Immunol. 2015;25:334-42.

14. Colas C, Monzon S, Venturini M, Lezaun A. Double-blind, placebo-controlled study with a modified therapeutic vaccine of Salsola kali (Russian thistle) administered through use of a cluster schedule. J Allergy Clin Immunol. 2006;117:810-6.

15. Gadermaier G, Hauser M, Ferreira F. Allergens of weed pollen: an overview on recombinant and natural molecules. Methods. 2014;66:55-66.

16. Laemmli UK. Cleavage of structural proteins during the assembly of the head of bacteriophage T4. Nature. 1970;227:680-5.

17. Ceska M, Lundkvist U. A new and simple radioimmunoassay method for the determination of $\mathrm{IgE}$. Immunochemistry 1972;9:1021-30.

18. Lieberman P, Nicklas RA, Oppenheimer J, Kemp SF, Lang DM, Bernstein DI, et al. The diagnosis and management of anaphylaxis practice parameter: 2010 update. J Allergy Clin Immunol. 2010;126:477-80 e42.

19. Mas S, Boissy P, Monsalve RI, Cuesta-Herranz J, Diaz-Perales A, Fernandez J, et al. A recombinant Sal $k 1$ isoform as an alternative to the polymorphic allergen from Salsola kali pollen for allergy diagnosis. Int Arch Allergy Immunol. 2015;167:8393.

20. Cuesta-Herranz J, Barber D, Blanco C, Cistero-Bahima A Crespo JF, Fernandez-Rivas $M$, et al. Differences among pollen-allergic patients with and without plant food allergy. Int Arch Allergy Immunol. 2010;153:182-92.

21. Musa F, Al-Ahmad M, Arifhodzic N, Al-Herz W. Compliance with allergen immunotherapy and factors affecting compliance among patients with respiratory allergies. Hum Vaccin Immunother. 2017;13(3):514-7.

- Manuscript received July 24, 2017; accepted for publication September 29, 2017.

\section{Mona Al-Ahmad}

Department of Microbiology, Faculty of Medicine, Kuwait University

P.O. Box 24923

Safat 13110 Kuwait

E-mail: Alahmadm@hsc.edu.kw 